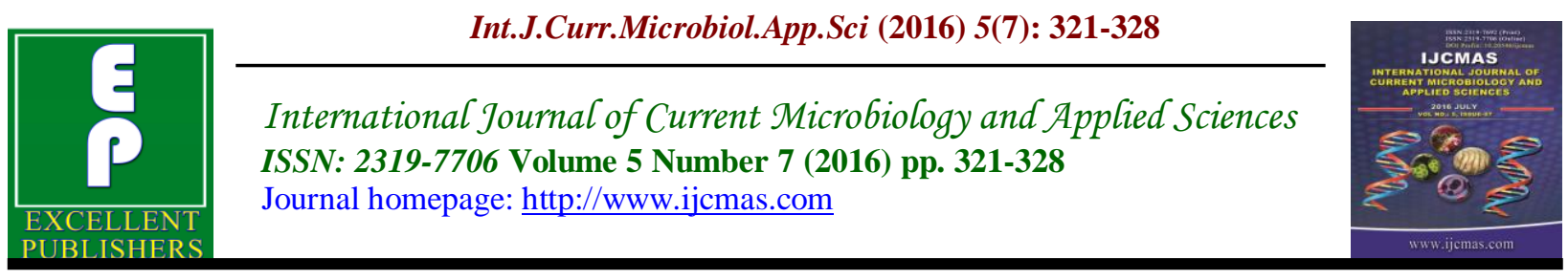

Original Research Article

http://dx.doi.org/10.20546/ijcmas.2016.507.034

\title{
Prevalence of Accessory Gene Regulator Specificity Groups among Methicillin Resistant Staphylococcus aureus Isolated from Iraqi Hospital Patients
}

\author{
Ali J. Saleem ${ }^{1 *}$, Munim R. Ali ${ }^{2}$ and Nizar E. Nasser ${ }^{2}$ \\ ${ }^{1}$ College of Education for Pure Science - Diyala University, Iraq \\ ${ }^{2}$ College of Science - Al-Mustansiriyah University, Iraq \\ *Corresponding author
}

\begin{tabular}{|c|c|}
\hline & A B S T R A C T \\
\hline Keywords & \multirow{3}{*}{$\begin{array}{l}\text { In current study, } 140 \text { clinical isolates of Staphylococcus aureus were collected from } \\
\text { different hospitals in Baghdad and Diyala. } 113 \text { of them were diagnosed as } \\
\text { Methicillin-resistant Staphylococcus aureus (MRSA) by two different methods } \\
\text { were used; phenotypic method was done by chromogenic MRSA agar and } \\
\text { genotypic method was done by Polymerase Chain Reaction (PCR) technique to } \\
\text { detection mecA gene. Multiplex PCR technique has been used to investigate } \\
\text { accessory gene regulator (agr) in } 113 \text { MRSA isolates and the results were } \\
84(74.34 \%) \text { isolates were belonged to agr group III, 26(23.01\%) isolates were } \\
\text { belonged to agr group I and } 3(2.65 \%) \text { isolates were untypable, while agr groups II } \\
\text { and IV were absent. }\end{array}$} \\
\hline tic & \\
\hline $\begin{array}{l}\text { Accepted: } \\
\text { 12 June } 2016 \\
\text { Available Online: } \\
\text { 10 July } 2016\end{array}$ & \\
\hline
\end{tabular}

\section{Introduction}

Staphylococcus aureus is a major human pathogen, responsible for a multitude of human infections around the world (Otto, 2012). This diversity is related to a number of virulence factors that are coordinately expressed during different stages of infection by intricate networks of transcriptional regulators and twocomponent signal transduction systems. The result allows it to adhere to surface, invade or avoid the immune system, and cause harmful toxic effects to the host (Bien et al., 2011).

Methicillin-resistant Staphylococcus aureus (MRSA) isolates emerged after the introduction of methicillin by acquisition of the mecA gene, which located on a mobile SCCmec cassette chromosome. This genetic element confers resistance to most currently available beta-lactam antibiotics (Katayama et al., 2000).

The expression of most virulence factors is controlled by global regulators such as accessory gene regulator and staphylococcal accessory regulator $\mathrm{A}$.

The accessory gene regulator (agr) is one of these virulence regulators, being a quorumsensing system activated by autoinducing peptide (AIP) or the so-called a bacterial 
density sensing peptide (Cotar et al., 2012). A polymorphism in the amino acid sequence of the AIP divides $S$. aureus strains into four major groups. Each group is characterized by a specific oligopeptide, in which only the thiolactone structure is conserved (Malone et al., 2007). Agr responsible for the upregulation in extracellular protein production and the down-regulation of cell wallassociated protein synthesis during the postexponential growth phase.

The agr locus is located on the S. aureus chromosome and is considered to be part of the core genome and not in the pathogenicity island (Novick, 1995). It is $3.5 \mathrm{~kb}$ in size and consists of two divergent transcriptional units, RNAII and RNAIII, whose transcription is driven by the $\mathrm{P} 2$ and P3 promoters, respectively (Le and Otto, 2015). The RNAII transcript is an operon of four genes, agrBDCA, that encode factors required to synthesize and sense AIP. AgrD is the precursor peptide of AIP and AgrB is an integral membrane endopeptidase essential to biosynthesize AIP. AgrC and AgrA form a two-component pair where AgrC is the membrane histidine kinase and AgrA is a response regulator (Novick, 2003; Li and Tian, 2012).

RNAIII is the major downstream effector of the agr system that post transcriptionally regulates expression of virulence factors. The RNAIII operon encodes a $\delta$-haemolysin and is itself a regulatory RNA that plays a key role in the $a g r$ response (De Kievit and Inglewski, 2000).

\section{Methods and Materials}

\section{Isolation of $s$. Aureus from clinical samples}

One hundred and forty $S$. aureus isolates were obtained from different hospitals in Baghdad and Diyala governorates. Including, ninety two isolates were collected from Baghdad hospitals; Ibn-El Balady,
Baghdad teaching hospital, Al-Numan Hospital and Alemam-Ali hospital during the period between February 2014 to May 2014, while forty eight isolates were collected from Diyala hospitals; Baqubah teaching hospital and Balad-Ruz general hospital during the period between April 2014 to July 2014. They were isolated from different clinical sites including: burn infections, ear infection, throat infection, surgical wound from hospitalized patient, midstream urine from patient suffering urinary tract infections, sputum of patients with respiratory tract infections and blood from patient with septicemia. Each isolate was identified according the morphology, biochemical tests and growth in Chromagar Staph.aureus, the growing colonies that appeared distinctive pink to mauve color diagnosed as S.aureus.

\section{Phenotypic detection of MRSA isolates}

The colonies were identified as $\mathrm{S}$. aureus by Chromagar Staph.aureus were transferred by sterile loop and directly inoculated on Chromagar MRSA and incubated at $37^{\circ} \mathrm{C}$ for $24 \mathrm{hr}$. On this medium, the growing colonies that appeared distinctive pink to mauve color diagnosed as MRSA.

\section{Genotypic detection of MRSA isolates}

The prevalence of MRSA isolates was done by using uniplex PCR with specific primer and amplicon size (Table 1) to detecting mecA gene. Genomic DNA of S.aureus was extracted according to boiling method described by klingenberg et al., (2004). PCR mixture was prepared by adding $12.5 \mu \mathrm{l}$ of GoTaq ${ }^{\circledR G r e e n ~ m a s t e r ~ M i x ~(2 X) ~ p r o m e g a, ~}$ $5 \mu 1$ template DNA, $1.5 \mu$ from each forward and reverse primers with final concentration $1 \mathrm{poml} / \mu \mathrm{l}$, finally volume was completed to $25 \mu 1$ by adding nuclease free water. 


\section{Genotypic detection of agr groups using PCR technology}

The prevalence of agr specific groups among MRSA isolates in this study was done by using multiplex PCR with specific primers and amplicon size (Table 1). Genomic DNA of S.aureus was extracted according to boiling method described by klingenberg et al., (2004).

PCR mixture was prepared by adding $12.5 \mu 1$ of GoTaq®Green master Mix (2X) promega, $5 \mu \mathrm{l}$ template DNA, $1 \mu \mathrm{l}$ from forward primer and $1 \mu \mathrm{l}$ from each four reverse primers with final concentration 1 poml $/ \mu$ l, finally volume was completed to $25 \mu 1$ by adding nuclease free water.

PCR condition illustrated in table (2) and PCR products were detected in $1 \%$ agarose gel for $1 \mathrm{hr}$. at $75 \mathrm{~V}$, stained with ethidium bromide and visualized by transilluminator.

\section{Results and Discussion}

\section{Isolation and identification of S.aureus}

In this study, all one hundred and forty clinical isolates produce clear $\beta$-hemolysis around their colonies Iin blood agar no growth was appeared in MacConkey agar. In manitol salt agar medium, all isolates caused fermentation of manitole and changed the color of colonies to yellow. Staining and microscopic examination showed that all isolates were gram-positive coccus and arranged in grape shape clearly.

All isolates were catalase positive and oxidase negative. The growing colonies on CHROMagar Staph aureus media appeared as pink to mauve due to the hydrolysis of chromogenic substrates including in media which confirms that they are colonies of $S$. aureus according to manufacture's instruction.

\section{Screening for MRSA}

Out of 140 S. aureus isolates $113(80.7 \%)$ were MRSA detected by the two methods chromogenic medium and PCR assay, including 65 isolates $(77.4 \%)$ of 84 isolates collected from Baghdad hospitals, while 48 isolates $(85.7 \%)$ of 56 isolates collected from Diyala hospitals. Table (3) summarizes the number and source of MRSA isolates which were collected from several hospitals in Baghdad and Diyala.

\section{Phenotypic method}

One hundred and forty $S$. aureus isolates cultured on CHROMagar MRAS media in order to diagnosis of methicillin-resistant than other, the growing colonies of 113 $(80.7 \%)$ S. aureus isolates appeared as pink to mauve due to the hydrolysis of chromogenic substrates including in media which indicates they are MRSA, while 27 (19.3\%) S. aureus isolates did not appear growth which indicates they are MSSA according to manufacture's instruction.

\section{Genotypic method}

All $S$. aureus islates were tested for mecA gene by PCR. The results revealed that Out of 140 S. aureus isolates $113(80.7 \%)$ were yielded mecA gene by PCR, the figure (1) shows the genetic detection of mecA gene to different isolates of the bacteria under study.

\section{Screening for agr groups}

Hundred and thirteen MRSA isolates from different hospital in Baghdad and Diyala used to study the prevalence $a g r$ groups in Iraq, it was screened by multiplex PCR technique. The results showed that $74.34 \%$ (84/113) isolates were belonged to agr group III, while $23.01 \%(26 / 113)$ isolates were belonged to $a g r$ group I and $2.65 \%$ (3 
/113) isolates were untypable (S17, S41 and S103). agr groups II and IV were not detected among all studied strains. Figure (4) shows the positive genetic detection of agr group I and III to different isolates of the bacteria under study. The findings of the study also showed that out of 65 MRSA isolates collected from patients in Baghdad were $22(33.85 \%)$ isolates belonged to $a g r$ group I, 41(63.07\%) belonged to $a g r$ group III and 2(3.07\%) isolates untypable, while out of 48 MRSA isolates collected from patients in Diyala were $4(8.33 \%)$ isolates belonged to agr group I, 44(89.58\%) belonged to agr group III and $1(2.08 \%)$ isolate untypable.

The first used this method for classification of $S$. aureus were Dufour and colleagues in 2002, they showed that isolates of this bacterium could be divided into four Groups, I, II, III, IV. The agr quorumsensing and signal transduction system was initially described in $S$. aureus based on the presence four distinct allelic variants have been sequenced.

In this study the predominant agr group found in clinical specimens were agr group III followed by agr group I, the absence of agr groups II and IV may be caused that they are uncommon in the region under study or they were present in MSSA isolates. Azimian et al. (2012) in Iran, showed that most of MRSA strains belonged to $a g r$ group I and III while most of MSSA strains belonged to agr groups II and IV, and the strains carrying $a g r$ group I and $a g r$ group III were more resistant to oxacillin than agr group II and agr group IV.

Table.1 Primers and amplified PCR products used in study

\begin{tabular}{|c|c|c|c|c|}
\hline $\begin{array}{l}\text { Primer } \\
\text { name }\end{array}$ & Primer sequences $\left(5^{\prime} \rightarrow 3^{\prime}\right)$ & $\begin{array}{l}\text { Product } \\
\text { size(bp) }\end{array}$ & origin & $\begin{array}{l}\text { Referenc } \\
\text { es }\end{array}$ \\
\hline agr 1 & $\begin{array}{l}\text { F- ATGCACATGGTGCACATGC } \\
\text { R- GTCACAAGTACTATAAGCTG CGAT }\end{array}$ & 441 & $\begin{array}{l}\text { Alpha } \\
\text { (Canada) }\end{array}$ & $\begin{array}{l}\text { Gilot } \text { et } \\
\text { al., } 2002\end{array}$ \\
\hline agr2 & $\begin{array}{l}\text { F- ATGCACATGGTGCACATGC } \\
\text { R- } \\
\text { TATTACTAATTGAAAAGTGCCATAGC }\end{array}$ & 575 & $\begin{array}{l}\text { Alpha } \\
\text { (Canada) }\end{array}$ & $\begin{array}{l}\text { Gilot et } \\
\text { al., } 2002\end{array}$ \\
\hline agr3 & $\begin{array}{l}\text { F- ATGCACATGGTGCACATGC } \\
\text { R- } \\
\text { GTAATGTAATAGCTTGTATAATAATA } \\
\text { C } \\
\text { CCAG }\end{array}$ & 323 & $\begin{array}{l}\text { Alpha } \\
\text { (Canada) }\end{array}$ & $\begin{array}{l}\text { Gilot et } \\
\text { al., } 2002\end{array}$ \\
\hline $\operatorname{agr} 4$ & $\begin{array}{l}\text { F- ATGCACATGGTGCACATGC } \\
\text { R- CGATAATGCCGTAATACCCG }\end{array}$ & 659 & $\begin{array}{l}\text { Alpha } \\
\text { (Canada) }\end{array}$ & $\begin{array}{l}\text { Gilot et } \\
\text { al., } 2002\end{array}$ \\
\hline mecA & $\begin{array}{l}\text { F- } \\
\text { GTAGAAATGACTGAACGTCCGATAA } \\
\text { R- CCAATTCCACATTGTTTCGGTCTAA }\end{array}$ & 310 & $\begin{array}{l}\text { OligoData } \\
\text { (S-Africa) }\end{array}$ & $\begin{array}{l}\text { McClure } \\
\text { et } \\
\text { al.2006 }\end{array}$ \\
\hline
\end{tabular}


Table.2 PCR condition to genes used in study

\begin{tabular}{|l|c|c|c|c|c|c|}
\hline $\begin{array}{c}\text { Amplified } \\
\text { gene }\end{array}$ & $\begin{array}{c}\text { Initial } \\
\text { denaturation }\end{array}$ & $\begin{array}{c}\text { No. of } \\
\text { cycles }\end{array}$ & Denaturation & Annealing & Elongation & $\begin{array}{c}\text { Final } \\
\text { extension }\end{array}$ \\
\hline$a g r$ & $94^{\circ} \mathrm{C} / 5 \mathrm{~min}$ & 30 & $94^{\circ} \mathrm{C} / 30 \mathrm{Sec}$ & $56^{\circ} \mathrm{C} / 1 \mathrm{~min}$ & $72^{\circ} \mathrm{C} / 1 \mathrm{~min}$ & $72^{\circ} \mathrm{C} / 7 \mathrm{~min}$ \\
\hline$m e c A$ & $95^{\circ} \mathrm{C} / 5 \mathrm{~min}$ & 35 & $94^{\circ} \mathrm{C} / 30 \mathrm{Sec}$ & $53^{\circ} \mathrm{C} / 1 \mathrm{~min}$ & $72^{\circ} \mathrm{C} / 1 \mathrm{~min}$ & $72^{\circ} \mathrm{C} / 7 \mathrm{~min}$ \\
\hline
\end{tabular}

Table.3 distribution of MRSA according to the region under study and source of isolation

\begin{tabular}{|c|c|c|c|c|c|c|}
\hline \multirow{2}{*}{$\begin{array}{l}\text { Source of } \\
\text { isolation }\end{array}$} & \multicolumn{2}{|c|}{ Baghdad hospitals } & \multicolumn{2}{|c|}{ Diyala hospitals } & \multirow{2}{*}{$\begin{array}{l}\text { No. of } \\
\text { MRSA }\end{array}$} & \multirow[t]{2}{*}{ Percentage } \\
\hline & MRSA & MSSA & MRSA & MSSA & & \\
\hline UTI & 14 & 6 & 14 & 2 & 28 & $24.78 \%$ \\
\hline Burn & 20 & 4 & 6 & 2 & 26 & $23.01 \%$ \\
\hline Wound & 16 & 3 & 7 & 3 & 23 & $20.35 \%$ \\
\hline Nasal infection & 6 & 2 & 11 & $\mathbf{0}$ & 17 & $15.04 \%$ \\
\hline Ear infection & 5 & 2 & 5 & 0 & 10 & $8.85 \%$ \\
\hline Blood & 3 & 2 & 2 & $\mathbf{0}$ & 5 & $4.42 \%$ \\
\hline Eye infection & $\mathbf{0}$ & $\mathbf{0}$ & 2 & 1 & 2 & $1.77 \%$ \\
\hline Sputum & 1 & 0 & 1 & $\mathbf{0}$ & 2 & $1.77 \%$ \\
\hline Total isolates & 65 & 19 & 48 & 8 & 113 & $100 \%$ \\
\hline
\end{tabular}

Fig.1 Agaros gel electrophoresis (1\% agarose,7v/cm2 for $60 \mathrm{~min}$ ) for mecA gene (310bp amplicon) lane M100bp DNA Ladder, lanes 1-12 represent of bands.

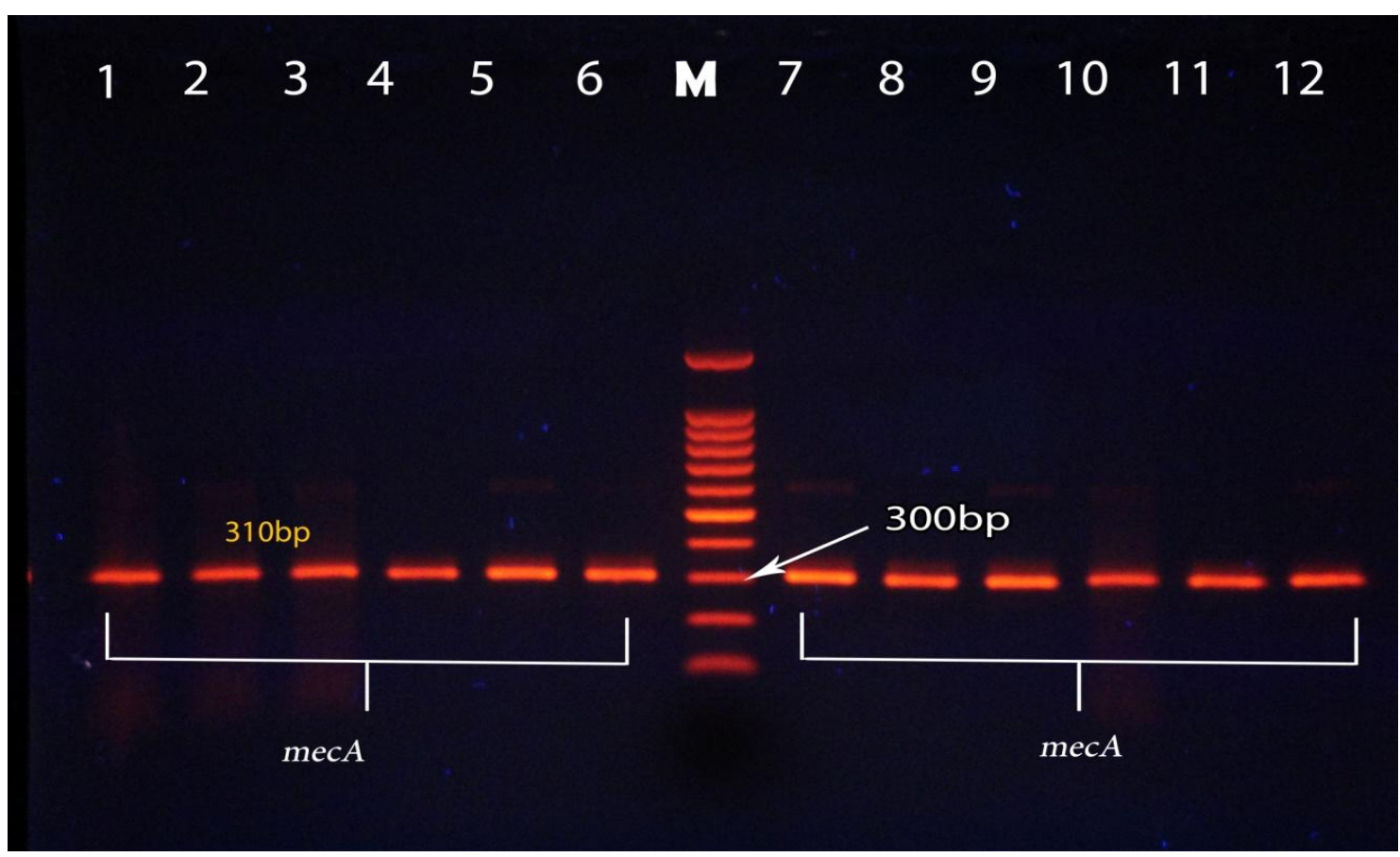


Fig.2 Agaros gel electrophoresis (1\% agarose, $7 \mathrm{v} / \mathrm{cm} 2$ for $60 \mathrm{~min}$ ) for agr I (441bp) and agr III genes (323bp) lane M100bp DNA Ladder, lanes 1-6 represent of agr I bands and lanes 7-12 represent of agr III bands.

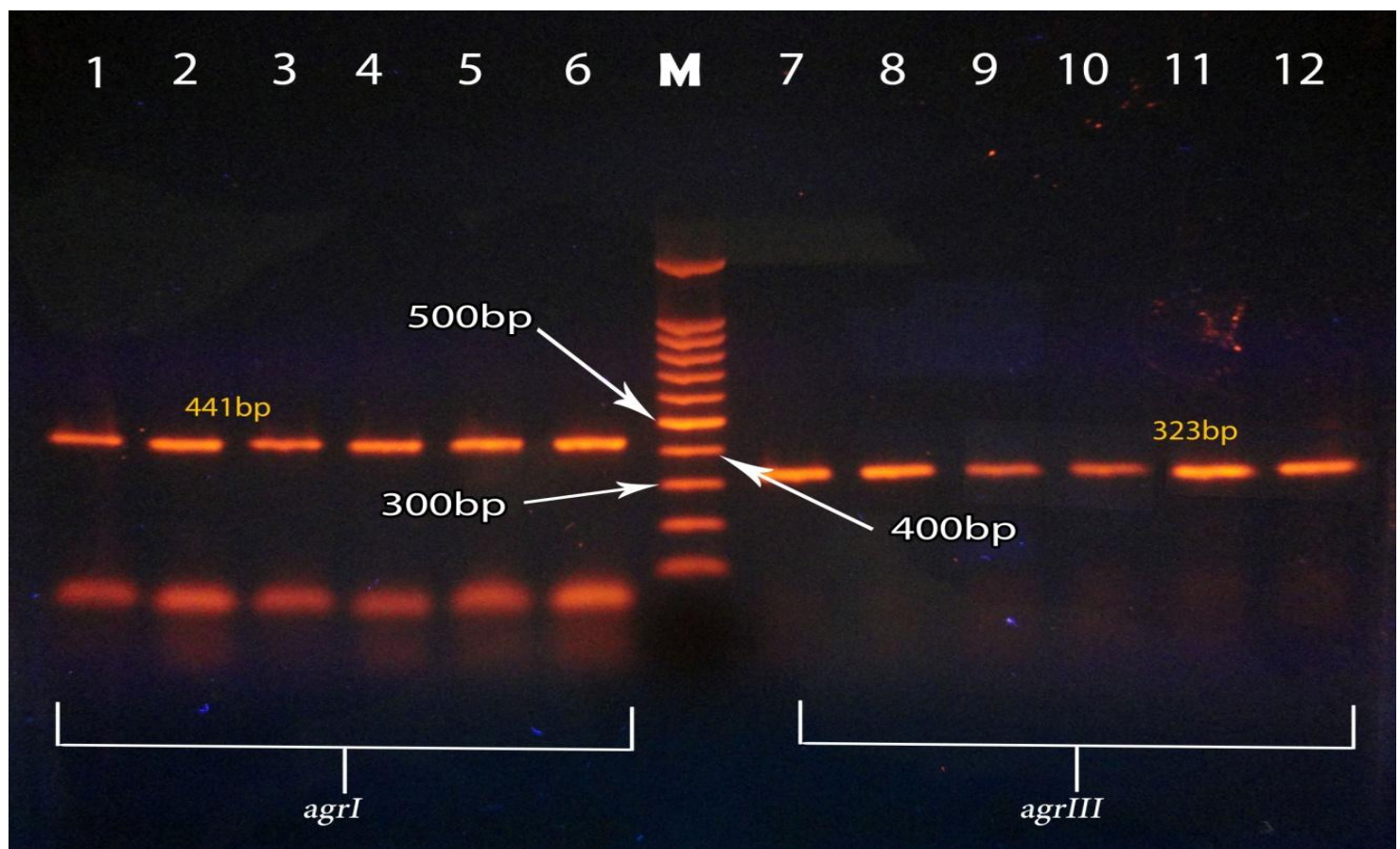

There are many studies done around the world to detect prevailing agr groups of $S$. aureus in those countries, some of which interested to detects agr groups in MRSA. Melake et al., (2014), in Egypt showed that most of MRSA strains which Isolated from nasal carriers belonged to agr group I followed by agr group II and III respectively, while agr groups IV not was not detected. Vaziri et al., (2016), in Iran found the predominant agr group of MRSA isolated from burn wound of hospitalized patient in Tehran was agr group I, while in another study done by Bibalan et al., (2016), showed that $a g r$ group III was predominant in MRSA strains in cases isolated from the clinical sample of patients in Iran and the agr group II was predominant in MSSA strains while the agr group I was the major agr groups in $S$. aureus that were recovered from health care workers and food products. Ayed et al., (2006) in Tunis were found agr group III were predominant type in MRSA strains that were isolated from patients. Strommenger et al., (2004) found that all of the MRSA strains that were isolated from central Europe belonged to agr group I, in contrast Dufour et al., (2002) showed that agr III the vast majority group of MRSA strains in France and around the world. While agr II was the predominant group in MRSA isolates collected from multiple centers around the United States (Goerke et al., 2005), Paniagua-Contreas et al., (2012) agreed with that in a study conducted in Mexico about the strains of MRSA collected from hemodialysis catheters of Mexican patients. Also Gomes et al. (2005) suggested that agr group II strains were mainly isolated in Japan and North America. The agr group IV was absent in many previously reported articles suggests that these strains does not have preference in the competition.

The results of previous studies suggest that the prevalence of predominant $a g r$ 
specificity groups vary from one country to another based on epidemiological and regional factors, in addition to the results affected by sampling biased.

\section{References}

Ayed, S.B., Boubaker, IB-B., Samir, E. and Redjeb, S.B. 2006. Prevalence of agr specificity groups among methicilin resistant Staphylococcus aureus circulating at Charles Nicolle hospital of Tunis. Pathologie Biologie., 54(8): 435-8.

Azimian, A., Najar-Pirayeh, S., MirabSamiee, S. and Naderi, M. 2012. Occurrence of methicillin resistant Staphylococcus aureus (MRSA) among clinical samples in tehran-iran and its correlation with polymorphism of specific accessory gene regulator (AGR) groups. Braz. J. Microbiol., 43: 779-85.

Bibalan, M.H., Shakeri, F., Javid, N. and Ghaemi, E. 2016. Study the Association of Accessory Gene Regulator Types and Methicillin Resistance/Sensitivity of Staphylococcus aureus Isolated in Gorgan, Iran Infect. Epidemiol. Med., 2(2): 1-4.

Bien, J., Sokolova, O. and Bozko, P. 2011. Characterization of virulence factors of Staphylococcus aureus: novel function of known virulence factors that are implicated in activation of airway epithelial proinflammatory response. J. Pathogens, 1-13.

Cotar, I.A., Chifiriuc, M.C., Holban, A.M., Banu, O. and Lazar, V. 2012. Prevalence of agr specificity Groups among Staphylococcus aureus strains isolated from different clinical specimens patients with cardiovascular surgery associated infections. Biointerface Res. Appl. Chem., 2: 264-
70.

Dekievit, T. and Inglewski, B.H. 2000. Bacterial Quorum Sensing in Pathogenic Relationships. Infection and Immunity, 68: 4839-4849.

Dufour, P., Jarraud, S., Vandenesch, F., Greenland, T., Novick, R.P. and Bes, M. 2002. High genetic variability of the agr locus in Staphylococcus species. J. Bacteriol., 184(4): 11801186.

Gilot, P., Lina, G., Cochard, T. and Poutrel, B. 2002. Analysis of the genetic variability of genes encoding the RNA III-activating components Agr and TRAP in a population of Staphylococcus aureus strains isolated from cows with mastitis. J. Clin. Microbiol., 40(11): 4060-4067.

Goerke, C., Esser, S., Kummel, M. and Wolz, C. 2005. Staphylococcus aureus strain designation by agr and cap polymorphism typing and delineation of agr diversification by sequence analysis. Int. J. Med. Microbiol., 295: 67-75.

Gomes, A.R., Vinga, S., Zavolan, M. and De Lencastre, H. 2005. Analysis of the genetic variability of virulence-related loci in epidemic clones of MethicillinResistant Staphylococcus aureus. Antimicrob Agents Chemother., 49: 366-379.

Katayama, Y., Ito, T. and Hiramatsu, K. 2000. A new class of genetic element, staphylococcus cassette chromosome mec, encodes methicillin resistance in Staphylococcus aureus. Antimicrobial Chemother., 44: 1549-1555.

Klingenberg, C., Sundsfjord, A., Rønnestad, A., Mikalsen, J., Gaustad, P. and Flaegstad, T. 2004. Phenotypic and genotypic aminoglycoside resistance in blood culture isolates of coagulasenegative staphylococci from a single neonatal intensive care unit. $J$. 
Antimicrob. Chemother., 54: 889-896.

Le, K.Y. and Otto, M. 2015. Quorumsensing regulation in staphylococcian overview. Front. Microbiol., 6: 1174

Li, Y.H. and Tian, X.L. 2012. Quorum sensing and bacterial social interactions in biofilms. Sensors, 12: 2519-2538.

Malone, C.L., Boles, B.R. and Horswill, A.R. 2007. Biosynthesis of Staphylococcus aureus autoinducing peptides by using the Synechocystis DnaB Mini-Intein. Appl. Environ. Microbiol. 73:6036-6044.

McClure, J.A., Conly, J.M., Lau, V., Elsayed, S., Louie, T., Hutchins, W. and Zhang, K. 2006. Novel multiplex PCR assay for detection of the staphylococcal virulence marker Panton-Valentine leukocidin genes and simultaneous discrimination of methicillin-susceptible from -resistant staphylococci. J. Clin. Microbiol., 44: 1141-1144.

Melake, N.A., Zakaria, A.S., Ibrahim, N.H., Salama, M.A. and Mahmoud, A.Z. 2014. Prevalence of Agr Specificity Groups among in vitro Biofilm Forming Methicillin Resistant Staphylococcus aureus Strains Isolated from Nasal Carriers. Int. J. Microbiol. Res., 5: 76-84.

Novick, R.P., Projan, S.J., Kornblum, J., Ross, H.F., Ji, G., Kreiswirth, B., Vandenesch, F. and Moghazeh, S. 1995. The agr P2 operon: an autocatalytic sensory transduction system in Staphylococcus aureus. Mol. Gen. Genet., 248(4): 446-58.

Novick, R.P. 2003. Autoinduction and signal transduction in the regulation of staphylococcal virulence. Mol. Microbiol., 48: 1429-1449.

Otto, M. 2012. MRSA virulence and spread. Cell. Microbiol., 14: 1513-21.

Paniagua- Contreras, G., Sainz-Eespnes, T., Monroy-Perez, E., Raymundo Rodriguez-Moctezuma, J., ArenasAranda, D., Negrete-Abascal, E. and Vaca, S. 2012. Virulence Markers in Staphylococcus aureus Strains Isolated from Hemodialysis Catheters of Mexican Patients. Adv. Microbiol., 2: 476-487.

Strommenger, B., Cuny, C., Werner, G. and Witte, W. 2004. Obvious lack of association between dynamics of epidemic methicillin-resistant Staphylococcus aureus in central Europe and agr specificity groups. Eur J Clin Microbiol Infect Dis., 23(1): 159.

Vaziri, M.S., Mirzaii, M., Moghadam, H.K., Fazli, M., Khoramrooz, S.S., Sarokhalil, D.D. and Yaslianifard, S. 2015. The Relationship Between Antibiotic Resistance and Agr Type in Methicillin-Resistant Staphylococcus aureus (MRSA) Isolated From Burn Wound of Hospitalized Patient in Tehran. Knowledge \& Health J., 11(1): $1-7$.

\section{How to cite this article:}

Ali J. Saleem, Munim R. Ali and Nizar E. Nasser. 2016. Prevalence of Accessory Gene Regulator Specificity Groups among Methicillin Resistant Staphylococcus aureus Isolated from Iraqi Hospital Patients. Int.J.Curr.Microbiol.App.Sci. 5(7): 321-328. doi: http://dx.doi.org/10.20546/ijcmas.2016.507.034 